EXPERIMENTAL AND COMMERCIALLY-AVAILABLE WINES FINED WITH EGG

\title{
WHITE PROTEINS
}

4

5 Francesca Uberti ${ }^{1}$, Roberta Danzi ${ }^{2}$, Creina Stockley ${ }^{3}$, Elena Peñas ${ }^{1}$, Cinzia Ballabio ${ }^{1}$, Chiara Di

6 Lorenzo $^{1}$, Chiara Tarantino ${ }^{4}$, Patrizia Restani ${ }^{1}$

7

8 1. Dipartimento di Scienze Farmacologiche e Biomolecolari, Università degli Studi di

$9 \quad$ Milano, via Balzaretti 9, 20133 Milano - Italy

10 2. Unione Italiana Vini, via San Vittore al Teatro 3, 20123 Milano - Italy

11 3. The Australian Wine Research Institute, PO Box 197, Glen Osmond, South Australia

125064 - Australia

13 4. Euroclone SpA, via Figino 20/22, 20016 Pero (MI) - Italy

14

15

$16 *$ Author to whom correspondence should be addressed

17 Prof. Patrizia Restani

18 Dept. Pharmacological Sciences, Università degli Studi di Milano

19 Via Balzaretti 9, 20133 Milano (Italy)

20 Tel.: + $390250318350-8371$

21 Fax: +390250318284

22 Email: patrizia.restani@unimi.it 


\section{Abstract}

Proteinaceous egg whites are widely used as a fining agent during red winemaking. The

26 presence of residues of egg white in the final wine could, however, represent a risk for egg

27 allergic individuals. The aim of the study was to investigate the presence of allergenic residues

28 in red and white wines fined with egg whites. Different experimental and commercially-

29 available wines fined with egg whites, with or without subsequent bentonite fining, were

30 included in this study. Unfined wines were examined as negative controls. The physicochemical

31 characteristics of each wine were determined to assess their possible role in enhancing or

32 hindering the elimination of allergenic residues from wine. The amount of egg white protein

33 residues was investigated both by an ELISA test, specifically developed, and by

34 immunoblotting. Both immunochemical tests used the same anti-total egg white protein

35 antibody and showed high sensitivity to detect traces of allergen. No egg white protein was

36 detected in the wines studied in both immunochemical tests, irrespective of the physicochemical

37 characteristics of the wine, the type and dosage of the fining agent and the oenological

38 processed used. Hence, the risk of adverse reactions in egg allergic individuals should be

39 considered negligible.

40

41 Key words: wine, allergenic residues, egg white proteins, fining agent

42

43

44

45 
48 impact on wine quality. The aim of the fining process can be three-fold: to soften or reduce its

49 astringency and/or bitterness; to clarify and remove proteins capable of haze formation; and/or

50 to stabilise and reduce the colour by the adsorption and precipitation of polymeric phenolic

51 compounds and tannins. ${ }^{1}$ Nowadays, a range of proteinaceous fining agents are used, including

52 gelatine, milk proteins, egg proteins, isinglass and, more recently, proteins derived from plants

53 such as wheat and white lupin. ${ }^{2,3}$ Water-soluble egg white (albumin or albumen) is the most

54 commonly used fining agent in red winemaking. It has a positively charged surface that binds

55 with negatively charged compounds such as tannins. The high molecular weight of the resulting

56 aggregates allows their mechanical elimination by racking and/or filtration prior to bottling or

57 further maturation. A second fining agent may be used, such as the inorganic fining agent

58 bentonite, that adsorbs proteins thus helping to remove residual proteinaceous fining agents

59 from the wine. ${ }^{4}$

Egg white contains several allergenic proteins such as ovalbumin, ovomucoid,

61 ovotransferrin and lysozyme..$^{5-7}$

62 If fining agents are used and removed according to a good manufacturing practice, it

63 can be assumed that these proteins are not present in the final wine product. Good manufacturing practice for fining is essentially defined as using the smallest amount of fining agent needed to achieve the desired result followed by racking and pre-bottling filtration processes (Organisation de la Vigne et du Vin 2012). To date there is limited evidence, however, that wines in the marketplace are free from residues of proteinaceous fining agents. In addition, the several studies that have evaluated wines for residual protein have had conflicting results perhaps partially reflecting different analytical methodologies as well as differences in manufacturing practice. ${ }^{8-12}$ The presence of allergenic proteins in wine could cause an adverse reaction in sensitized individuals, although the prevalence of allergy to egg proteins is rare in 
adults. It is less rare, however, in children ( $c$ a. $0.6-2.6 \%$ ), but generally resolves by six to seven years of age. ${ }^{13-17}$

The European Union adopted the Directive 2003/89/EC, ${ }^{18}$ last amended by Directive 2007/68/EC, ${ }^{19}$ which contains a list of allergenic substances (Annex III), including egg and egg derivatives that have to be declared on the label of foodstuffs. EC Directive 2005/26/EC ${ }^{20}$ listed food ingredients that were provisionally excluded from the labelling requirement; inclusion of wine fining agents in this list was postponed until June 2012 to allow for further study since there was limited scientific data concerning their actual presence or absence in fined wines ${ }^{19,21}$. It should be noted that the inclusion of a statement such as "contains egg proteins" on the wine label can contribute to the uncertainty of consumers (allergic or not), simultaneously damaging the "quality perception" of the product.

The present study was aimed to investigate the presence of allergenic residues in 14

84

85 86 in the present work.

Experimental wines included red wines fined with 3 or $10 \mathrm{~g} / \mathrm{hL}$ of egg white, both concentrations with the subsequent addition of $0,10,20$ or $30 \mathrm{~g} / \mathrm{hL}$ of bentonite. All wine samples were microfiltrated through a $3 \mu \mathrm{m}$-membrane pore size. The detailed characteristics of these 14 experimental wines are listed in Table 1. A further group of 12 wines which were not 
99 from five different countries were included in this study. Among them, 48 red wines and one 100 white wine were supplied by Italian winemakers; seven of these samples were untreated wines

101 and were used as negative controls. Other wines were from France (20 samples), Australia (12

102 samples), New Zealand (two samples) and Spain (two samples). Only wines where the

103 oenological practices were known were included in this study. The detailed list of the 84

104 commercially-available wine samples studied, including their physicochemical characteristics,

105 is presented in Table 2. The agents used during wine fining were the following: Albapur

106 (Tecnofood, Italy); Albovo (Oliver Ogar, Italy); Albuclar (Vason Group, Italy); Albumin Dry

107 (Enolife srl, Italy); Egg albumin (Dal Cin SpA, Sesto San Giovani, Italy); Albumin powder

108 (Laffort Oenologie, France); Albumin powder (Lamothe Abiet, France); Blancoll (Esseco srl,

109 Italy); Oviclair (La Littorale, France); Ovoclar (Pall Corporation, Italy); Ovoclaryl (Laffort,

110 France); and Ovocol L (Martin Vialatte Oenology, France).

111 2.2. Physicochemical characteristics of wines

112 The following physicochemical characteristics were evaluated for the wine samples:

113 2.2.1. Alcoholic strength by volume (\% vol.).

114 It is defined as the number of litres of ethanol contained in 100 litres of wine, measured

115 at $20^{\circ} \mathrm{C}$. This method involves distilling wine volume by volume; the volumetric weight of the

116 distillate is measured by electronic densitometry using a frequency oscillator. ${ }^{22}$

117 2.2.2. Total alcoholic strength by volume.

118 It is a calculation of the potential alcohol concentration if all remaining sugars were to

119 be fermented. It is calculated by adding potential alcoholic strength to alcoholic strength by volume. $^{23}$

Potential alcoholic strength by volume is defined as the number of volumes of pure alcohol at $20^{\circ} \mathrm{C}$ produced by total fermentation of the sugars contained in 100 volumes of the product at that temperature and it is calculated by multiplying the concentration of reducing sugars $(\mathrm{g} / \mathrm{L})$ by 0.06 . 
128 concentration $<5 \mathrm{~g} / \mathrm{L})$ was diluted 1:2 (v:v) with water; sweet wine was suitably diluted to reach the values reported above. Red wine was clarified with solutions of neutral lead acetate and calcium carbonate (Merck KgaA, Darmstadt, Germany). A specific quantity of an alkaline solution of copper salts is heated and the copper ions are titrated by the clarified/diluted wine, in the presence of methylene blue as indicator (UIV internal method, 2009). 2.2.4. Total acidity.

Wine total acidity was determined by acid-base potentiometric titration, using $0.1 \mathrm{~N}$ $\mathrm{NaOH}$, to $\mathrm{pH} 7$, with an automatic titrator. ${ }^{22}$ 2.2.5. Volatile acidity.

To determinate the volatile acidity of wines, carbon dioxide was first removed from the

138 wine sample. Volatile acids were then separated from wine by steam distillation and titrated

139 using $\mathrm{NaOH}$. The acidity of free and combined sulphur dioxide distilled under these conditions 140 was substracted from the acidity of the distillate, after filtration by standard iodine solution. ${ }^{25}$

141 2.2.6. $\mathrm{pH}$.

142 The $\mathrm{pH}$ value of wine samples was determined by potentiometry using a calibrated $\mathrm{pH}-$

143 meter. $^{26}$ 2.2.7. Ash content.

Ash amount was measured by ignition of wine extract at $500-550^{\circ} \mathrm{C}$ until the complete combustion (oxidation) of organic material had been achieved. Then, the residue obtained after combustion was weighed using a balance having sensitivity of $0.1 \mathrm{mg} .^{27}$ 2.2.8. Total dry extract and reduced extract. alcohol-free wine, after measuring the specific gravity at $20^{\circ} \mathrm{C}$ of the wine and of the water- 

the difference between the total dry extract and the reducing sugars in excess of $1 \mathrm{~g} / \mathrm{L} .{ }^{28}$ 2.2.9. Total phenolic compounds.

The total phenolic compounds were analysed using the Folin-Ciocalteau Method, with some modifications. ${ }^{29}$ Wine samples were diluted and then mixed with the Folin-Ciocalteau reagent, which oxidizes all the phenolic compounds, and sodium carbonate (Merck KgaA, Darmstadt, Germany). Afterwards, absorbance was measured at $760 \mathrm{~nm}$. 2.2.10. Anthocyanins. Total anthocyanins were determined according to Di Stefano and Cravero ${ }^{30}$ with some modifications. Briefly, wine samples were diluted with an acidulated ethanol-water solution. The absorbance spectrum was then determined between 420 and $620 \mathrm{~nm}$.

\subsection{SDS-PAGE and Immunoblotting}

Wine samples were analyzed by SDS-PAGE according to Ballabio et al., ${ }^{31}$ on a gel having the following characteristics:

167 Gradient running gel: 9-19\% acrylamide; 0.08-0.17\% bis-acrylamide; $0.36 \mathrm{M}$ TRIS-HCl

168 buffer $\mathrm{pH} 8.8 ; 35 \%$ glycerol; $0.1 \%$ SDS; $0.02 \%$ ammonium persulfate; and $0.15 \% \mathrm{~N}, \mathrm{~N}, \mathrm{~N}^{\prime}, \mathrm{N}^{\prime}-$ 169 tetramethylenediamine (TEMED).

170 Stacking gel: $3.5 \%$ acrylamide; $0.09 \%$ bis-acrylamide; $0.125 \mathrm{M}$ TRIS-HCl buffer $\mathrm{pH}$ 6.8; $1710.1 \%$ SDS; $0.02 \%$ ammonium persulfate; and $0.15 \%$ (TEMED).

172 Running buffer: $25 \mathrm{mM}$ TRIS, $0.19 \mathrm{M}$ glycine and 0.1\% SDS (w/v), pH 8.8 .

173 Sample buffer: The composition of the $2 x$ sample buffer was: $0.25 \mathrm{M}$ Tris-HCl buffer $\mathrm{pH} 6.8$, $17422.5 \%$ glycerol, $2 \%$ SDS and $5 \% \beta$-mercaptoethanol.

175 Purified egg proteins and fining agents were diluted in water at the final concentration of 4 $176 \mathrm{mg} / \mathrm{mL}$ and then mixed with $2 \mathrm{x}$ sample buffer $(1: 1, \mathrm{v} / \mathrm{v})$. Regarding wines, aliquots of $1 \mathrm{~mL}$ of 177 each wine sample were dried under nitrogen at room temperature until a dry extract was 178 obtained. Afterwards, $200 \mu \mathrm{L}$ of a solution containing water: $2 \mathrm{x}$ sample buffer $(1: 1, \mathrm{v} / \mathrm{v})$ were 
added to the dry extract. Sample aliquots of $25 \mu \mathrm{L}$ were loaded onto the gel. Prestained SDS-

180 PAGE standard Broad Range (BioRad), containing proteins in the range 6,7-202,8 $\mathrm{kDa}$, was

181 used to control the electrophoretic run.

182

After the electrophoretic run, proteins were transferred onto a PVDF membrane

(Millipore, Billerica, MA) by western blotting in a Trans-blot Electrophoretic Transfer Cell

(Bio-Rad). The membranes were blocked with $1 \%$ gelatin and washed three times with $0.25 \%$

gelatin solution (150 mM NaCl, $5 \mathrm{mM}$ TRIS, $0.05 \%$ Triton-X) to prevent non-specific adsorption of the immunological reagents. Afterwards, the membrane was immersed in $10 \mathrm{~mL}$ of $0.25 \%$ gelatin solution containing $10 \mu \mathrm{L}$ of rabbit anti-total egg white protein IgG polyclonal antibodies. This antibody was specifically developed for this research using total egg proteins for immunization according to common protocols of sensitization. The antibody was characterized in order to ensure its capability to detect the different egg white allergens. Antigen-IgG complexes were detected by using $10 \mu \mathrm{L}$ of goat anti-rabbit IgG antibodies labeled with peroxidase (Sigma Aldrich, Milan, Italy). The developing solution contained DAB (3,3' diaminobenzidine) Plus substrate and DAB Plus Chromogen (Sigma Aldrich).

A sandwich ELISA kit (Euroclone SpA, Pero, Milano), specifically developed for the quantification of egg white proteins in wine was used..$^{32}$ It is a sandwich ELISA where the microplate is first coated with the specific anti-egg white protein antibody also used in immunoblotting; after incubation with the wine sample, a secondary anti-egg white protein antibody conjugated with horse radish peroxidase (HRP) is added to form a sandwich. To determine the detection limit (LOD) and the quantification limit (LOQ) the protocol described in the OIV "Compendium of international methods of analysis" E-AS1-10-LIMDET ${ }^{33}$ was used. The limits were calculated according to the procedure "Determination on blank" using the data 

standard solutions contained increasing amounts of egg proteins and spiked wine samples containing egg white in the range 0-7 ppm were used. All standards and wines were diluted 1:5 (v/v) with the buffer supplied with the kit. Statistical analysis of the obtained results was performed according to UNI ISO 5725-2:2004 an to the OIV "Compendium of international methods of analysis" MA-EAS1-07-ETCOL; the repeatability and reproducibility of the ELISA method were determined.

\section{Results}

The present research examined 84 commercially-available bottled wines collected from five different countries and 14 experimental wines, fined by adding egg white proteins with or without subsequent bentonite fining. Untreated wines were evaluated in parallel as negative controls. Most of the samples were red wine since egg white proteins are generally only used to fine red wines. ${ }^{2}$

\subsection{Physicochemical properties}

Different physicochemical characteristics were studied in the wine samples in order to assess, in the case that allergenic residues were detected, their possible role in inhibiting or enhancing the elimination of allergens during the fining process. The results are presented in

223 Table 1 (experimental wines) and Table 2 (commercially-available wines).

\subsection{SDS-PAGE and silver staining}

SDS-PAGE was assayed for its sensitivity using silver staining. ${ }^{34}$ For these purposes, decreasing quantities of oenological egg white proteins were loaded onto the gel, and the detection limit was calculated, resulting to be $0.78 \mu \mathrm{g}$ of oenological egg albumin (data not shown). 
of false-positive responses, unfined wines were also analysed by this technique. Some protein bands were present in all untreated wine samples, but they were associated with grapes (data not shown). The presence of these bands in the SDS-PAGE gels makes difficult the evaluation of the possible presence of egg white proteins when present in trace amounts. For this reason, SDS-PAGE has been used for the separation step but not for the quantification of allergenic residues.

\subsection{Specificity of anti-egg white protein antibody}

Since the quality of antibody is critical in immunochemical determinations, several antibodies specifically developed for this project were characterized by its binding capacity versus the main proteins contained in the fining agent (egg white proteins). Two of these antibodies were developed versus total egg white proteins and two versus the ovomucoid protein, since ELISA plates used for the detection of egg white allergens in food are usually coated with anti-ovomucoid antibodies. Figure 1 illustrates the specifity of the selected anti-total egg white protein antibody. It recognized all albumen proteins (ovotransferrin, ovomucoid, ovalbumin and lysozyme). Anti-ovomucoid antibodies (not shown) bound different egg white proteins but their affinities were lower and for this reason considered unsuitable for the aim of this project. The selected antibody was also used to coat the ELISA plates.

The binding capacity of the selected antibody was also verified with most fining agents, containing egg white proteins, present in the marketplace. The antibody recognized the egg white proteins in all fining agents evaluated and the differences in the bound affinity depended on the percentage of each egg white protein present in each product (not shown). 

blotting decreasing quantities of oenological egg white proteins onto a PVDF membrane and incubating them with the anti-total egg white protein antibody selected. The lowest detectable amount of egg white protein in immunoblotting was $1.5 \mathrm{ng}$ corresponding to $0.122 \mathrm{mg} / \mathrm{L}$ in the wine sample.

Once the limit of detection was calculated, the different wine samples were examined by immunoblotting. In order to check the possible presence of false-positive responses, unfined wines were also studied as negative controls. Figure 2 illustrates, as an example, the results of the immunoblotting performed on some wine samples. All experimental and commercial wines analyzed in the present work contained undetectable residues of egg white proteins, as listed in Tables 1 and 2. As expected, no egg white protein was found in the unfined wines.

\subsection{ELISA test}

The ELISA test used in the present work was specifically developed for this investigation to detect traces of egg white proteins in wine and was validated by a collaborative inter-laboratory study involving 11 laboratories. This method showed a reliable limit of detection of $0.056 \mathrm{mg} / \mathrm{L}$ in wine and a limit of quantification of $0.158 \mathrm{mg} / \mathrm{L}$. The quality parameters of the method (reproducibility, repeatability and robustness) were in line with the criteria established by the Organisation Internationale de la Vigne et du Vin (OIV) in the Compendium of International Methods of Analysis. ${ }^{35}$ None of the wine samples contained detectable amount of egg white proteins, regardless of the physicochemical properties of the wine, type and concentration of the fining agent used, as well as of the oenological practices employed on experimental and commercial wines, as shown in Tables 1 and 2. As expected, all unfined wines were free of egg white proteins (data not shown). 
Egg allergy is one of the most common food allergies in infancy and childhood, affecting $1-2 \%$ of young children. ${ }^{36}$ Although its prevalence in adults is considerably lower ${ }^{13-16 \text {, }}$ ${ }^{37}$, the presence of egg white proteins in fined wines should be avoided to protect the most sensitized subjects. To our knowledge, no case of an allergic reaction after wine consumption due to the presence of residues of egg white protein has been reported and this is despite unlabelled egg white fined wines peing in the marketplace in countries such as Canada, EU, $\underline{\text { USA and those of South East Asia which currently do not require allergen labelling for wine or }}$ have only recently inmplemented itThis could be due to the actual absence of residues or to the consumers' and/or doctors' lack of awareness about the oenological practice of fining with egg white proteins.

This study showed that no egg proteins were detected in any of the 77 commerciallyavailable wines analysed (detection limit of $0.0564 \mathrm{mg} / \mathrm{L}$ ), and that this was independent of the physicochemical characteristics of wines, despite the wide range of values for each parameter included. Specifically, this result was independent from: both experimental and commercially-available wines.

Our findings are consistent with those reported by Rolland et al. ${ }^{18}$ who did not find any residue of ovalbumin in 40 commercially-available Australian wines fined with egg white proteins. The same research group found no significant clinical response in a group of adult egg allergic subjects tested by a double-blind, placebo-controlled challenge with egg white protein fined wines. ${ }^{8}$ It should be emphasized that although other ELISA tests previously reported ${ }^{9,11}$ show good quality characteristics, our method was specifically developed in wine samples in commercial form, in order to standardize its performances and to make it available for wine producers and laboratories involved in quality control. 
312 Mediterranean countries, but these adverse reactions were associated with grape proteins ${ }^{38-41}$ or

313 to intolerances to acetaldehyde, biogenic amines such as tyramine or sulphur dioxide. ${ }^{42-44}$

314 The identification of the threshold safe for the most sensitive individuals is critical.

315 Bindslev-Jensen, Briggs and Osterballe ${ }^{45}$ defined a threshold value for egg of $8.6 \mathrm{mg}$ that would

316 protect $99 \%$ of egg allergic individuals. Moneret-Vautrin and Kanny ${ }^{46}$ reported that $18 \%$ of egg

317 allergic individuals can react to a concentration equal to or lower than $65 \mathrm{mg}$, while the

318 threshold for egg white capable of triggering an allergic reaction in $1 \%$ of sensitized people was

319 between 1 and $2 \mathrm{mg}$. Similarly, Morriset et al. ${ }^{47}$ performed a double-blind, placebo-controlled

320 food challenge with egg allergic individuals and reported that the lowest adverse effect level

321 (LOAEL) for crude egg was $2 \mathrm{mg}$.

322 Taking into account these values, the limit of detection of the methods used in this study

$323(0.0564 \mathrm{mg} / \mathrm{L})$ and the limit of quantification $(0.1578 \mathrm{mg} / \mathrm{L})$ should be more than sufficient to

324 protect egg allergic individuals. In fact, an egg allergic individual drinking 1 litre of wine at the

325 limit of detection level would consume less than $0.06 \mathrm{mg}$ of egg white. This 'acute' dose is

326 conservative given it is relatively 'difficult' to drink 1 litre of wine at a single drinking occasion,

327 and the risk of an allergic reaction from consuming wine should be considered negligible even

328 in the most sensitized subjects. 
332 This study (VINALL) was funded by the Italian Ministero dell'Agricoltura e delle Politiche

333 Agricole e Forestali (MIPAAF).

334 We thank Marie Madeleine Caillet for helping us in collecting wines from France as well as

335 Accolade Wines, McWilliam's Wines, Pernod_Ricard, Treasury Wine Estates and Yalumba.

\section{References}

337 (1) Yokosuka, K.; Singleton, V. L. Interactive precipitation between phenolic fractions and 338 peptides in wine-like model solution: turbidity, particle size and residual content as influenced by $\mathrm{pH}$, temperature and peptide concentration. Am. J. Enol. Vit. 1995, 46, 329-338.

(2) Ribéreau-Gayon, P.; Glories, Y.; Maujean, A.; Dubourdieu, D. The chemistry of wine stabilization and treatments. In Handbook of enology; John Wiley \& Sons: Chichester, UK, 2000, Vol. 2.

(3) Cosme, F.; Ricardo-da-Silva, J. M.; Laureano, O. Interactions between protein fining agents and proanthocyanidins in white wine. Food Chem. 2008, 106, 536-544.

(4) D’Amato, A.; Kravchuk, A.V.; Bachi, A.; Righetti, P. G. Noah's Nectar: the proteome content of a glass of red wine. J. Proteomics. 2010, 73, 2370-2377.

(5) Hoffman, D. R. Immunochemical identification of the allergens in egg white. J. Allergy Clin. Immunol. 1983, 71, 481-486.

(6) Bernhisel-Broadbent, J.; Dintzis, H. M.; Dintzis, R. Z.; Sampson H. A. Allergenicity and antigenicity of chicken egg ovomucoid (Gal d III) compared with ovoalbumin (Gal d I) in children with egg allergy and in mice. J. Allergy Clin. Immunol.1994, 93, 10471054.

(7) Mine, Y.; Zhang, J. W. Comparative studies on antigenicity and allergenicity of native and denatured egg white proteins. J. Agric. Food Chem. 2002, 50, 2679-2683.

(8) Rolland, J. M.; Apostolou, E.; Deckert, K.; de Leon, M. P.; Douglass, J. A.; Glaspole I. 

$22,882-888$

(9) Rolland, J. M., Apostolou, E., de Leon, M. P., Stockley, C. S., \& O’Hehir, R. E. Specific and sensitive enzyme-linked immunosorbent assays for analysis of residual allergenic food proteins in commecial bottled wine fined with egg white, milk, and non grape-derived tannins. J. Agric. Food Chem. 2008, 56, 349-356.

(10) Lifrani, A.; Dos Santos, J.; Dubarry M.; Rautureau, M.; Blachier, F.; Tome, D. Development of animal models and sandwich-ELISA tests to detect the allergenicity and antigenicity of fining agent residues in wines. J. Agric. Food Chem. 2009, 57, 525534.

(11) Weber, P.; Steinhart, H.; Paschke, A. Determination of the bovine food allergen casein in white wines by quantitative indirect ELISA, SDS-PAGE, western Blot and immunostaining. J. Agric. Food Chem. 2009, 57, 8399-8405.

(12) Restani, P.; Uberti, F.; Danzi, R.; Ballabio, C.; Pavanello, F.; Tarantino, C. Absence of allergenic residues in experimental and commercial wines fined with caseinates. Food Chem. (accepted).

(13) Sampson H. A. (2004). Update on food allergy. J. Allergy Clin. Immunol. 2004, 113, 805-19.

(14) EFSA. Opinion of the Scientific Panel on Dietetic Products, Nutrition and Allergies on a request from the Commission related to a notification from WFA and the AWRI on albumin (egg white) used in the manufacture of wine pursuant to Article 6, paragraph 11 of Directive 2000/13/EC- for permanent exemption from labelling. The EFSA J. $\mathbf{2 0 0 7}, 566,1-7$.

(15) Asero, R.; Antonicelli, L.; Arena, A.; Bommarito, L.; Caruso, B.; Crivellaro, M.; De Carli, M.; Della Torre, E.; Della Torre, F.; Heffler, E.; Lodi Rizzini, F.; Longo, R.; 
Manzotti, G.; Marcotulli, M.; Melchiorre, A.; Minale, P.; Morandi, P.; Moreni, P.; Moschella, A.; Murzilli, F.; Nebiolo, F.; Poppa, M.; Randazzo, S.; Rossi, G.; Senna, G. E. EpidemAAITO: Feature of food allergy in Italian adults attending allergy clinics: a multi-centre study. Clin. Exp. Allergy. 2009, 39, 547-555.

(16) Asero, R.; Antonicelli, L.; Arena, A.; Bommarito, L.; Caruso, B.; Colombo, C.; Crivellaro, M.; De Carli, M.; Della Torre, E.; Della Torre, F.; Heffler, E.; Lodi Rizzini, F.; Longo, R.; Manzotti, G.; Marcotulli, M.; Melchiorre, A.; Minale, P.; Morandi, P.; Moreni, P.; Moschella, A.; Murzilli, F.; Nebiolo, F.; Poppa, M.; Randazzo, S.; Rossi, G.; Senna, G. E. Cases of food-induced anaphylaxis in Italian Adults: a multi centre study. Int. Arch. Allergy Immunol. 2009, 150, 271-277.

(17) Clark, A. T.; Skypala, I.; Leech, S. C.; Ewan, P. W.; Dugué, P.; Brathwaite, N.; Huber, P. A.; Nasser, S. M. British Society for Allergy and Clinical Immunology guidelines for the management of egg allergy. Clin. Exp. Allergy. 2010, 40, 1116-1129.

(18) Commission of the European Communities. Directive 2003/89/EC of $10^{\text {th }}$ of November 2003 amending Directive 2000/13/EC as regards indication of the ingredients present in foodstuffs. Off. J. Eur. Union. 2003, L 308, 15-18.

(19) Commission of the European Communities. (2007) Directive 2007/68/EC of 27 November 2007 amending Annex IIIa of the Directive 2000/13/EC of the European Parliament and of the Council as regards certain food ingredients. Off. J. Eur. Union. 2007, $L 310,15-18$.

(20) Commission of the European Communities. Directive 2005/26/EC of 21 March 2005 establishing a list of food ingredients or substances provisionally excluded from Annex IIIa of the Directive 2000/13/EC of the European Parliament and of the Council. Off. J. Eur. Union. 2005, L 75, 33-44.

(21) Commission of the European Communities. Commission Regulation (EC) No 607/2009 of 14 July 2009 laying down certain detailed rules for the implementation of Council Regulation (EC) No 479/2008 as regards protected designations of origin and 

sector products. Off. J. Eur. Union. 2009, L 193, 60-80.

(22) OIV MA-E-AS312-01-TALVOL 2009. Compendium of International Methods of Wine and Must Analysis.

(23) Commission of the European Communities. Total alcoholic strength by volume Reg. 491/09/EC All I + All III GU. 2009, L 154 17/06/2009.

(24) OIV-ACITOT. OIV MA-E-AS313-01-ACITOT. Compendium of International Methods of Wine and Must Analysis. 2009.

(25) OIV-ACIVOL. OIV MA-E-AS313-02-ACIVOL. Compendium of International Methods of Wine and Must Analysis. 2009.

(27) OIV-CENDRE. OIV MA-E-AS2-04-CENDRE. Compendium of International Methods of Wine and Must Analysis. 2009.

(30) Di Stefano, R.; Cravero, M. C. I composti fenolici e la natura del colore dei vini rossi.

$$
\text { L'enotecnico. 1989, 10, 81-87. }
$$

(31) Ballabio, C.; Bertino, E.; Coscia, A.; Fabris, C.; Fuggetta, D.; Molfino, S.; Testa, T.; Sgarella, M. C.; Sabatino, G.; Restani, P. Immunoglobulin-A profile in breast milk from mothers delivering full-term and pre-term infants. Int. J. Immunopathol. Pharmacol. 2007, 20, 119-128.

(32) Restani, P.; Uberti, F.; Ballabio, C.; Di Lorenzo, C.; Persico, A.; Tarantino, C. Development of analytical methods to detect egg allergens in wines according to the EU Directive on labelling. Le Bulletin de l'OIV. 2010, 83, 367-374.

(33) OIV-LIMDET. OIV E-AS1-10-LIMDET. Compendium of International Methods of Wine and Must Analysis. 2009. 
(34) Gromova, I.; Celis, J. E. Protein detection in gels by silver staining: a procedure compatible with mass-spectrometry. In Cell Biology: A Laboratory Handbook; Celis J. E., Carter N., Hunter T., Simons K., Small J. V., D. Shotton, Eds.; Academic Press: San Diego, California, 2006; pp. 219-225.

(35) OIV-ETCOL. OIV MA-EAS1-07-ETCOL. Compendium of International Methods of Wine and Must Analysis. 2009.

(36) Heine, R. G.; Laske, N.; Hill, D. J. The diagnosis and management of egg allergy. Curr. Allergy Asthma Rep. 2006, 6, 145-152.

(37) Vierk, K. A.; Koehler, K. M.; Fein, S. B.; Street, D. A. Prevalence of self-reported food allergy in American adults and use of food labels. J. Allergy Clin. Immunol. 2007, 119, 1504-1510.

(38) Pastorello, E. A.; Farioli, L.; Pravettoni, V.; Ortolani, C.; Fortunato, D.; Giuffrida, M. G.; Garoffo, L. P.; Calamari, A. M.; Brenna, O.; Conti, A. Identification of grape and wine allergens as an endochitinase 4, a lipid-transfer protein, and a thaumatin. J. Allergy Clin. Immunol. 2003, 111, 350-359.

(39) Borghesan, F.; Basso, D.; Chieco Bianchi, F.; Favero, E.; Plebani, M. Allergy to wine. Allergy. 2004, 59, 1135-1136.

(40) Kalogeromitros, D. C.; Makris, M. P.; Gregoriou, S. G.; Katoulis, A. C.; Straurianeas, N. G. Sensitization to other foods in subjects with reported allergy to grapes. Allergy Asthma Proc. 2006, 27, 68-71.

(41) Schad, S. G.; Trcka, J.; Vieths, S.; Scheurer, S.; Conti, A.; Brocker, E. B.; Trautmann, A. Wine anaphylaxis in a German patient: IgE-mediated allergy against a lipid transfer protein of grapes. Int. Arch. Allergy Immunol. 2005, 136, 159- 164.

(42) Dahl, R.; Henriksen J. M.; Harving, H. Red wine asthma: a controlled challenge study. 
(43) Littlewood, J. T.; Gibb, C.; Glover, V.; Sandler, M.; Davies, P. T.; Rose F. C. Red wine as a cause of migraine. The Lancet. 1988, 1, 558-559.

(44) Alibrandi, B.; Parodi, A.; Varadlo, G. Purpura due to ethanol. N. Engl. J. Med. 1990, 322,702 .

(45) Bindslev-Jensen, C.; Briggs, D.; Osterballe, M. Can we determine a threshold level for allergenic foods by statistical analysis of published data in the literature?. Allergy. 2002, 57, 741-746.

(46) Moneret-Vautrin, D. A.; Kanny, G. Update on threshold doses of food allergens: implications for patients and the food industry. Curr. Opin. Allergy Clin. Immunol. 2004, 4, 215-219.

(47) Morisset, M.; Moneret-Vautrin D. A.; Kanny, G.; Guénard, L.; Beaudouin, E.; Flabbée, J.; Hatahet, R. Thresholds of clinical reactivity to milk, egg, peanut and sesame in immunoglobulin E-dependent allergies: evaluation by double-blind or single-blind placebo-controlled oral challenges. Clin. Exp. Allergy. 2003, 33, 1046-1051 
Table 1. Physico-chemical characteristics and allergenic residues of experimental red wines

\begin{tabular}{|c|c|c|c|c|c|c|c|c|c|c|c|c|c|c|c|}
\hline Sample & Oenological treatment & $\begin{array}{c}\text { ASV } \\
(\mathrm{mL} / 100 \mathrm{~mL})\end{array}$ & $\begin{array}{c}\text { TAS } \\
(\mathrm{mL} / 100 \mathrm{~mL})\end{array}$ & $\begin{array}{l}\text { RS } \\
\text { (g/L) }\end{array}$ & $\begin{array}{l}\text { Specific gravity } \\
\text { (g/L) }\end{array}$ & $\mathrm{pH}$ & $\begin{array}{l}\text { TDE } \\
(\mathrm{g} / \mathrm{L})\end{array}$ & $\begin{array}{c}\text { RE } \\
(\mathrm{g} / \mathrm{L})\end{array}$ & $\begin{array}{c}\text { TA } \\
(\mathrm{g} / \mathrm{L})\end{array}$ & $\begin{array}{c}\text { VA-SO } \\
\text { (g/L) }\end{array}$ & $\begin{array}{l}\text { Ash } \\
\text { (g/L) }\end{array}$ & $\begin{array}{c}\text { TPC } \\
\text { (mg/L) }\end{array}$ & $\begin{array}{c}\text { TAC } \\
(\mathrm{mg} / \mathrm{L})\end{array}$ & ELISA & IMM \\
\hline $1 \mathrm{~A}$ & - & 16.99 & 17.12 & 2.2 & 0.99220 & 3.51 & 35.8 & 34.6 & 5.5 & 0.55 & 2.82 & 2190 & 182 & $\mathrm{Neg}$ & $\mathrm{Neg}$ \\
\hline $2 \mathrm{~A}$ & $10 \mathrm{~g} / \mathrm{hL}$ egg white & 16.67 & 16.86 & 3.1 & 0.99325 & 3.53 & 37.4 & 35.3 & 5.6 & 0.60 & 2.90 & 2428 & 126 & Neg & $\mathrm{Neg}$ \\
\hline $3 \mathrm{~A}$ & $10 \mathrm{~g} / \mathrm{hL}$ egg white $+10 \mathrm{~g} / \mathrm{hL}$ bentonite & 17.01 & 17.17 & 2.7 & 0.99274 & 3.54 & 36.9 & 35.2 & 5.6 & 0.59 & 2.93 & 2236 & 126 & Neg & $\mathrm{Neg}$ \\
\hline $4 \mathrm{~A}$ & $10 \mathrm{~g} / \mathrm{hL}$ egg white $+20 \mathrm{~g} / \mathrm{hL}$ bentonite & 17.18 & 17.33 & 2.5 & 0.99242 & 3.53 & 36.6 & 35.1 & 5.6 & 0.61 & 2.83 & 2530 & 119 & Neg & $\mathrm{Neg}$ \\
\hline $5 \mathrm{~A}$ & $10 \mathrm{~g} / \mathrm{hL}$ egg white $+30 \mathrm{~g} / \mathrm{hL}$ bentonite & 16.83 & 17.02 & 3.1 & 0.99303 & 3.53 & 36.9 & 34.8 & 5.6 & 0.60 & 2.90 & 2571 & 120 & Neg & $\mathrm{Neg}$ \\
\hline $6 \mathrm{~A}$ & $3 \mathrm{~g} / \mathrm{hL}$ egg white $+10 \mathrm{~g} / \mathrm{hL}$ bentonite & 17.01 & 17.15 & 2.4 & 0.99276 & 3.51 & 37.0 & 35.6 & 5.6 & 0.61 & 2.90 & 2643 & 122 & $\mathrm{Neg}$ & $\mathrm{Neg}$ \\
\hline $7 \mathrm{~A}$ & $3 \mathrm{~g} / \mathrm{hL}$ egg white $+20 \mathrm{~g} / \mathrm{hL}$ bentonite & 16.99 & 17.15 & 2.6 & 0.99278 & 3.52 & 36.8 & 35.2 & 5.6 & 0.60 & 2.90 & 2402 & 125 & Neg & $\mathrm{Neg}$ \\
\hline $8 \mathrm{~A}$ & $3 \mathrm{~g} / \mathrm{hL}$ egg white $+30 \mathrm{~g} / \mathrm{hL}$ bentonite & 16.95 & 17.12 & 2.9 & 0.99281 & 3.53 & 36.8 & 34.9 & 5.5 & 0.61 & 2.92 & 2453 & 124 & Neg & $\mathrm{Neg}$ \\
\hline $1 \mathrm{~V}$ & - & 13.03 & 13.12 & 1.5 & 0.99408 & 3.34 & 29.0 & 28.5 & 6.0 & 0.38 & 2.79 & 1672 & 270 & Neg & $\mathrm{Neg}$ \\
\hline $2 \mathrm{~V}$ & $10 \mathrm{~g} / \mathrm{hL}$ egg white & 12.98 & 13.09 & 1.9 & 0.99413 & 3.32 & 29.1 & 28.2 & 6.4 & 0.69 & 2.80 & 1805 & 124 & Neg & $\mathrm{Neg}$ \\
\hline $3 \mathrm{~V}$ & $10 \mathrm{~g} / \mathrm{hL}$ egg white $+10 \mathrm{~g} / \mathrm{hL}$ bentonite & 13.10 & 13.21 & 1.9 & 0.99385 & 3.31 & 28.6 & 27.7 & 6.3 & 0.71 & 2.71 & 1824 & 120 & Neg & $\mathrm{Neg}$ \\
\hline $4 \mathrm{~V}$ & $10 \mathrm{~g} / \mathrm{hL}$ egg white $+20 \mathrm{~g} / \mathrm{hL}$ bentonite & 12.49 & 12.60 & 1.9 & 0.99472 & 3.32 & 29.0 & 28.1 & 6.1 & 0.55 & 2.76 & 1828 & 132 & Neg & $\mathrm{Neg}$ \\
\hline $5 \mathrm{~V}$ & $10 \mathrm{~g} / \mathrm{hL}$ egg white $+30 \mathrm{~g} / \mathrm{hL}$ bentonite & 12.63 & 12.73 & 1.6 & 0.99447 & 3.34 & 28.7 & 28.1 & 6.0 & 0.47 & 2.71 & 1897 & 132 & $\mathrm{Neg}$ & $\mathrm{Neg}$ \\
\hline $6 \mathrm{~V}$ & $3 \mathrm{~g} / \mathrm{hL}$ egg white $+10 \mathrm{~g} / \mathrm{hL}$ bentonite & 13.16 & 13.25 & 1.5 & 0.99375 & 3.32 & 28.5 & 28.0 & 5.9 & 0.45 & 2.76 & 1738 & 100 & Neg & $\mathrm{Neg}$ \\
\hline $7 \mathrm{~V}$ & $3 \mathrm{~g} / \mathrm{hL}$ egg white $+20 \mathrm{~g} / \mathrm{hL}$ bentonite & 13.15 & 13.22 & 1.2 & 0.99387 & 3.32 & 28.8 & 28.6 & 6.0 & 0.45 & 2.73 & 1834 & 124 & Neg & $\mathrm{Neg}$ \\
\hline $8 \mathrm{~V}$ & $3 \mathrm{~g} / \mathrm{hL}$ egg white $+30 \mathrm{~g} / \mathrm{hL}$ bentonite & 12.87 & 12.97 & 1.6 & 0.99422 & 3.33 & 28.9 & 28.3 & 6.0 & 0.50 & 2.75 & 1832 & 129 & $\mathrm{Neg}$ & $\mathrm{Neg}$ \\
\hline
\end{tabular}

A: Amarone wine; V: Valpolicella wine; ASV: Alcoholic Strength by Volume; TAS: Total Alco
Total Phenolic Compounds; TAC: Total Anthocyanins; IMM: Immunoblotting; Neg: negative. 
Table 2. Physico-chemical characteristics and allergenic residues of commercial wines-part I-VI

\begin{tabular}{|c|c|c|c|c|c|c|c|c|c|c|c|c|c|c|c|c|c|c|c|}
\hline $\mathbf{N}^{0}$ & Wine name & Origin & $\begin{array}{c}\text { Fining } \\
\text { agent }\end{array}$ & $\begin{array}{c}\text { F. agent } \\
\text { concentration } \\
(\mathrm{g} / \mathrm{hL})\end{array}$ & BEN & $\begin{array}{c}\mathrm{ASV} \\
(\mathrm{mL} / \mathbf{1 0 0} \\
\mathrm{mL})\end{array}$ & $\begin{array}{c}\text { TAS } \\
(\mathrm{mL} / 100 \mathrm{~mL})\end{array}$ & $\begin{array}{c}\mathbf{R S} \\
(\mathrm{g} / \mathrm{L})\end{array}$ & $\begin{array}{l}\text { Specific } \\
\text { gravity } \\
(\mathrm{g} / \mathrm{L})\end{array}$ & pH & $\begin{array}{l}\text { TDE } \\
(\mathrm{g} / \mathrm{L})\end{array}$ & $\begin{array}{c}\mathbf{R E} \\
(\mathrm{g} / \mathbf{L})\end{array}$ & $\begin{array}{c}\text { TA } \\
(\mathrm{g} / \mathrm{L})\end{array}$ & $\begin{array}{l}\text { VA } \\
(\mathrm{g} / \mathbf{L})\end{array}$ & $\begin{array}{l}\text { ASH } \\
(\mathrm{g} / \mathbf{L})\end{array}$ & $\begin{array}{l}\text { TPC } \\
(\mathrm{mg} / \mathrm{L})\end{array}$ & $\begin{array}{c}\text { TAC } \\
(\mathrm{mg} / \mathrm{L})\end{array}$ & ELISA & IMM \\
\hline 1 & $\begin{array}{l}\text { Chianti classico Riserva } \\
\text { Fontale DOCG }\end{array}$ & Italy & No albumin & - & NO & 14.05 & 14.11 & 1.0 & 0.99257 & 3.16 & 29.3 & 29.3 & 6.2 & 0.33 & 2.12 & 1731 & 229 & $\mathrm{Neg}$ & $\mathrm{Neg}$ \\
\hline 2 & $\begin{array}{l}\text { Chianti classico Riserva - } \\
\text { Vigneti La Selvanella DOCG } \\
2006\end{array}$ & Italy & No albumin & - & NO & 13.39 & 13.45 & 1.0 & 0.99282 & 3.20 & 27.2 & 27.2 & 5.7 & 0.25 & 2.11 & 1630 & 306 & $\mathrm{Neg}$ & $\mathrm{Neg}$ \\
\hline 3 & $\begin{array}{l}\text { Merlot delle Maestrelle } \\
\text { (Santa Cristina) IGT2008 }\end{array}$ & Italy & No albumin & - & NO & 13.14 & 13.33 & 3.2 & 0.99460 & 3.43 & 30.1 & 27.9 & 5.4 & 0.37 & 2.61 & 1687 & 418 & Neg & $\mathrm{Neg}$ \\
\hline 4 & $\begin{array}{c}\text { Il Bruciato - Bolgheri DOC } \\
2007\end{array}$ & Italy & No albumin & - & NO & 14.32 & 14.40 & 1.3 & 0.99284 & 3.37 & 29.7 & 29.4 & 5.6 & 0.46 & 2.51 & 1944 & 259 & $\mathrm{Neg}$ & $\mathrm{Neg}$ \\
\hline 5 & $\begin{array}{l}\text { Badia a Passignano - Chianti } \\
\text { Classico DOCG } 2007\end{array}$ & Italy & No albumin & & NO & 14.23 & 14.29 & 1.0 & 0.99385 & 3.43 & 31.7 & 31.7 & 5.8 & 0.52 & 3.01 & 2193 & 368 & Neg & $\mathrm{Neg}$ \\
\hline 6 & $\begin{array}{c}\text { Il Bruciato - Bolgheri DOC } \\
2008\end{array}$ & Italy & No albumin & - & NO & 14.37 & 14.43 & 1.0 & 0.99311 & 3.42 & 30.1 & 30.1 & 5.6 & 0.47 & 2.78 & 2059 & 246 & $\mathrm{Neg}$ & $\mathrm{Neg}$ \\
\hline 7 & $\begin{array}{l}\text { Badia a Passignano - Chianti } \\
\text { Classico DOCG } 2006\end{array}$ & Italy & No albumin & - & NO & 13.57 & 13.65 & 1.4 & 0.99273 & 3.38 & 27.1 & 26.7 & 5.7 & 0.49 & 2.39 & 2001 & 155 & $\mathrm{Neg}$ & $\mathrm{Neg}$ \\
\hline 8 & $\begin{array}{l}\text { Rosso Toscano "i coltri" IGT } \\
2007\end{array}$ & Italy & Egg white & 4.5 & YES & 13.31 & 13.42 & 1.8 & 0.99340 & 3.37 & 28.4 & 27.6 & 5.2 & 0.38 & 2.72 & 1636 & 284 & $\mathrm{Neg}$ & $\mathrm{Neg}$ \\
\hline 9 & Chianti DOCG 2008 & Italy & Egg white & 4 & YES & 12.69 & 12.81 & 2.0 & 0.99407 & 3.39 & 28.5 & 27.5 & 5.3 & 0.4 & 2.47 & 1881 & 415 & $\mathrm{Neg}$ & Neg \\
\hline 11 & $\begin{array}{l}\text { Lambrusco Grasparossa di } \\
\text { Castelvetro - Passione vino } \\
\text { secco frizzante DOC }\end{array}$ & Italy & Ovoclar & 10 & YES & 10.24 & 11.03 & 13.1 & 1.00057 & 2.11 & 33.6 & 21.5 & 7.1 & 0.20 & 3.84 & 1164 & 220 & $\mathrm{Neg}$ & $\mathrm{Neg}$ \\
\hline 12 & Taurasi DOCG 2000 & Italy & Albuclar & 10 & NO & 14.16 & 14.28 & 2.0 & 0.99383 & 3.32 & 32.2 & 31.2 & 7.1 & 0.57 & 2.28 & 2658 & 185 & Neg & Neg \\
\hline 13 & Chianti Classico 2006 & Italy & Ovoclar & 7 & NO & 13.39 & 13.48 & 1.5 & 0.99261 & 3.30 & 26.9 & 26.4 & 6.0 & 0.42 & 2.22 & 2322 & 121 & $\mathrm{Neg}$ & $\mathrm{Neg}$ \\
\hline 14 & $\begin{array}{l}\text { Alturio - Refosco dal Ped. } \\
\text { Roso DOC } 2005\end{array}$ & Italy & Blancoll & 6 & YES & 13.60 & 13.75 & 2.5 & 0.99362 & 3.40 & 30.1 & 28.6 & 6.0 & 0.39 & 2.76 & 2535 & 455 & $\mathrm{Neg}$ & Neg \\
\hline 15 & $\begin{array}{c}\text { Sangiovese maremma } \\
\text { toscana IGT } 2008\end{array}$ & Italy & Ovoclar & 8 & YES & 13.55 & 13.69 & 2.4 & 0.99382 & 3.43 & 29.6 & 28.2 & 5.8 & 0.44 & 2.53 & 1848 & 289 & $\mathrm{Neg}$ & Neg \\
\hline
\end{tabular}




\begin{tabular}{|c|c|c|c|c|c|c|c|c|c|c|c|c|c|c|c|c|c|c|c|}
\hline 16 & $\begin{array}{l}\text { Oltrepò Pavese - Pinot nero } \\
\text { Poggio Pelato DOC } 2005\end{array}$ & Italy & Blancoll & 20 & YES & 13.49 & 13.57 & 1.3 & 0.99160 & 3.55 & 25.4 & 25.1 & 5.2 & 0.64 & 2.68 & 3013 & 66 & $\mathrm{Neg}$ & $\mathrm{Neg}$ \\
\hline 17 & $\begin{array}{l}\text { Oltrepò pavese - Bonarda } \\
\text { vivace DOC } 2008\end{array}$ & Italy & Blancoll & 6 & YES & 11.84 & 12.55 & 11.9 & 0.99783 & 2.97 & 34.1 & 23.2 & 6.7 & 0.24 & 2.13 & 1947 & 363 & $\mathrm{Neg}$ & $\mathrm{Neg}$ \\
\hline 18 & $\begin{array}{l}\text { Montepulciano d'Abruzzo } \\
\text { DOC } 2008\end{array}$ & Italy & Blancoll & 10 & YES & 12.42 & 12.83 & 6.8 & 0.99659 & 3.43 & 34.3 & 28.5 & 5.9 & 0.43 & 2.65 & 2004 & 320 & $\mathrm{Neg}$ & $\mathrm{Neg}$ \\
\hline 19 & $\begin{array}{l}\text { Negroamaro Cabernet } \\
\text { Sauvignon IGT } 2007\end{array}$ & Italy & Albapur & 4 & YES & 13.43 & 13.97 & 9.0 & 0.99921 & 3.74 & 43.8 & 35.8 & 5.7 & 0.56 & 4.03 & 2764 & 348 & $\mathrm{Neg}$ & $\mathrm{Neg}$ \\
\hline 20 & $\begin{array}{l}\text { Salice salentino - Masseria } \\
\text { Trajone DOC } 2005\end{array}$ & Italy & Albapur & 4 & YES & 13.14 & 13.75 & 10.2 & 0.99990 & 3.65 & 44.3 & 35.1 & 5.9 & 0.52 & 3.83 & 2780 & 275 & $\mathrm{Neg}$ & $\mathrm{Neg}$ \\
\hline 21 & $\begin{array}{l}\text { Primitivo di Manduria - } \\
\text { Epicuro } \\
\text { DOC } 2007\end{array}$ & Italy & Albapur & 4 & YES & 14.53 & 15.05 & 8.7 & 0.99875 & 3.85 & 46.0 & 38.3 & 5.6 & 0.59 & 4.22 & 2996 & 336 & $\mathrm{Neg}$ & $\mathrm{Neg}$ \\
\hline 22 & Aglianico IGT 2007 & Italy & Albuclar & 3 & NO & 12.69 & 13.13 & 7.4 & 0.99719 & 3.38 & 36.1 & 29.7 & 5.7 & 0.58 & 3.21 & 3239 & 356 & $\mathrm{Neg}$ & $\mathrm{Neg}$ \\
\hline 23 & $\begin{array}{l}\text { Vino Rosso Primitivo IGT } \\
2008\end{array}$ & Italy & Albumin dry & 10 & YES & 13.68 & 14.27 & 9.8 & 0.99962 & 3.61 & 45.4 & 36.6 & 5.5 & 0.59 & 3.46 & 2887 & 552 & Neg & $\mathrm{Neg}$ \\
\hline 24 & $\begin{array}{l}\text { Primitivo di Manduria - } \\
\text { Felline DOC } 2006\end{array}$ & Italy & Albumin dry & 20 & YES & 14.77 & 15.12 & 5.8 & 0.99705 & 3.47 & 41.2 & 36.4 & 6.6 & 0.47 & 3.59 & 2941 & 540 & $\mathrm{Neg}$ & $\mathrm{Neg}$ \\
\hline 25 & $\begin{array}{l}\text { Negroamaro del Salento - } \\
\text { Pietraluna Torreguaceto IGT } \\
2009\end{array}$ & Italy & Albumin dry & 20 & YES & 13.70 & 14.06 & 6.0 & 0.99792 & 3.33 & 40.3 & 35.3 & 7.3 & 0.42 & 3.28 & 2883 & 602 & $\mathrm{Neg}$ & $\mathrm{Neg}$ \\
\hline 26 & $\begin{array}{l}\text { Vino Rosso del Salento - } \\
\text { Alberello IGT } 2007\end{array}$ & Italy & Albumin dry & 20 & YES & 13.32 & 13.64 & 5.4 & 0.99740 & 3.40 & 37.9 & 33.5 & 6.3 & 0.42 & 3.36 & 2687 & 559 & $\mathrm{Neg}$ & $\mathrm{Neg}$ \\
\hline 27 & $\begin{array}{c}\text { Primitivo di Manduria - } \\
\text { Archidamo Peruini DOC } \\
2007\end{array}$ & Italy & Albumin dry & 20 & YES & 14.70 & 15.02 & 5.4 & 0.99699 & 3.42 & 41.3 & 36.9 & 6.8 & 0.38 & 3.41 & 3095 & 519 & $\mathrm{Neg}$ & $\mathrm{Neg}$ \\
\hline 28 & $\begin{array}{l}\text { Valpolicella classico DOC } \\
2007\end{array}$ & Italy & Ovoclar & 6 & YES & 13.33 & 13.60 & 4.5 & 0.99544 & 3.34 & 32.8 & 29.3 & 6.0 & 0.40 & 2.68 & 1777 & 241 & $\mathrm{Neg}$ & $\mathrm{Neg}$ \\
\hline 29 & $\begin{array}{l}\text { Merlot Colli Berici DOC } \\
2008\end{array}$ & Italy & Ovoclar & 4 & YES & 12.50 & 12.77 & 4.5 & 0.99552 & 3.39 & 31.1 & 27.6 & 5.6 & 0.33 & 2.86 & 1654 & 363 & $\mathrm{Neg}$ & $\mathrm{Neg}$ \\
\hline 30 & $\begin{array}{l}\text { Montepulciano d'Abruzzo- } \\
\text { Cerulli Spinozzi DOC } 2008\end{array}$ & Italy & Ovoclar & 4 & YES & 13.23 & 13.51 & 4.7 & 0.99553 & 3.30 & 33.4 & 29.7 & 6.4 & 0.45 & 2.54 & 2197 & 461 & $\mathrm{Neg}$ & $\mathrm{Neg}$ \\
\hline
\end{tabular}




\begin{tabular}{|c|c|c|c|c|c|c|c|c|c|c|c|c|c|c|c|c|c|c|c|}
\hline 31 & $\begin{array}{c}\text { Bardolino classico DOC } \\
2009\end{array}$ & Italy & Ovoclar & 3 & YES & 12.47 & 12.74 & 4.5 & 0.99572 & 3.32 & 30.9 & 27.4 & 5.6 & 0.30 & 2.64 & 1536 & 469 & $\mathrm{Neg}$ & $\mathrm{Neg}$ \\
\hline 32 & $\begin{array}{l}\text { Nero d'Avola Syrah - Feudo } \\
\text { Sartanna IGT } 2009\end{array}$ & Italy & Ovoclar & 3 & YES & 14.06 & 14.26 & 3.4 & 0.99501 & 3.42 & 33.3 & 30.9 & 5.7 & 0.45 & 2.83 & 2064 & 415 & $\mathrm{Neg}$ & $\mathrm{Neg}$ \\
\hline 33 & $\begin{array}{c}\text { Bardolino classico DOC } \\
2008\end{array}$ & Italy & Ovoclar & 4 & YES & 12.32 & 12.6 & 4.6 & 0.99576 & 3.25 & 30.9 & 27.3 & 5.5 & 0.30 & 2.66 & 1627 & 435 & $\mathrm{Neg}$ & Neg \\
\hline 34 & $\begin{array}{l}\text { Regolo rosso veronese IGT } \\
2006\end{array}$ & Italy & Ovoclar & 3 & YES & 13.84 & 14.26 & 7.0 & 0.99669 & 3.33 & 37.7 & 31.7 & 6.2 & 0.45 & 3.01 & 2255 & 324 & $\mathrm{Neg}$ & $\mathrm{Neg}$ \\
\hline 35 & $\begin{array}{c}\text { Bardolino - Murari DOC } \\
2008\end{array}$ & Italy & Ovoclar & 3 & YES & 12.2 & 12.49 & 4.9 & 0.99596 & 3.29 & 31.2 & 27.3 & 5.6 & 0.32 & 2.68 & 1450 & 400 & $\mathrm{Neg}$ & Neg \\
\hline 36 & $\begin{array}{c}\text { Valpolicella classico } \\
\text { superiore - Vigneti di } \\
\text { Montegradella DOC } 2006\end{array}$ & Italy & Ovoclar & 5 & YES & 13.59 & 13.95 & 6.0 & 0.99645 & 3.34 & 36.1 & 31.1 & 6.3 & 0.44 & 3.18 & 2141 & 280 & $\mathrm{Neg}$ & Neg \\
\hline 37 & $\begin{array}{c}\text { Valpolicella superiore } \\
\text { Ripasso - Vigneti di } \\
\text { Valdimezzo DOC } 2007\end{array}$ & Italy & Ovoclar & 8 & YES & 13.71 & 14.13 & 7.0 & 0.99701 & 3.35 & 37.4 & 31.4 & 6.1 & 0.42 & 3.23 & 2212 & 322 & $\mathrm{Neg}$ & Neg \\
\hline 38 & $\begin{array}{l}\text { Amarone della Valpolicella } \\
\text { DOC } 2005\end{array}$ & Italy & Ovoclar & 8 & YES & 15.25 & 15.73 & 8.0 & 0.99657 & 3.39 & 41.2 & 34.2 & 6.2 & 0.50 & 3.29 & 2426 & 221 & $\mathrm{Neg}$ & Neg \\
\hline 39 & $\begin{array}{l}\text { Aglianico - Vigne Sannite } \\
\text { IGT } 2008\end{array}$ & Italy & Albuclar & 5 & YES & 13.18 & 13.29 & 1.8 & 0.99388 & 3.38 & 29.8 & 29.0 & 6.1 & 0.59 & 2.45 & 2619 & 156 & $\mathrm{Neg}$ & $\mathrm{Neg}$ \\
\hline 40 & $\begin{array}{l}\text { Refosco dal Peduncolo } \\
\text { Rosso DOC } 2007\end{array}$ & Italy & $\begin{array}{l}\text { Potassium } \\
\text { Caseinate - } \\
\text { Egg White - } \\
\text { Lysozyme }\end{array}$ & $20+20$ & NO & 14.16 & 14.31 & 2.5 & 0.99526 & 3.46 & 35.7 & 34.2 & 6.1 & 0.59 & 3.62 & 2399 & 331 & $\mathrm{Neg}$ & Neg \\
\hline 41 & $\begin{array}{l}\text { Merlot - Daunia Teanum } \\
\text { Alta IGT } 2008\end{array}$ & Italy & Egg white & 30 & YES & 14.98 & 15.06 & 1.3 & 0.99615 & 3.54 & 38 & 37.7 & 5.4 & 0.40 & 3.32 & 3170 & 386 & $\mathrm{Neg}$ & $\mathrm{Neg}$ \\
\hline 42 & $\begin{array}{l}\text { Cabernet sauvignon Teanum } \\
\text { Alta IGT } 2008\end{array}$ & Italy & Egg white & 50 & YES & 13.54 & 13.68 & 2.3 & 0.99786 & 3.41 & 38.3 & 37.0 & 5.4 & 0.38 & 3.20 & 3474 & 491 & $\mathrm{Neg}$ & Neg \\
\hline 43 & Aglianico IGT 2008 & Italy & Egg white & 100 & YES & 14.3 & 14.4 & 1.7 & 0.99602 & 3.35 & 36.3 & 35.6 & 5.6 & 0.38 & 2.89 & 3337 & 344 & $\mathrm{Neg}$ & Neg \\
\hline 44 & Lareith Sudtirol Lagrein & Italy & Blancoll & 4 & $\begin{array}{l}\mathrm{YES} \\
15 \mathrm{~g} / \mathrm{hL}\end{array}$ & 13.27 & 13.39 & 2.0 & 0.99499 & 3.47 & 30.6 & 29.6 & 5.3 & 0.51 & 3.23 & 2956 & 644 & $\mathrm{Neg}$ & Neg \\
\hline 45 & $\begin{array}{c}\text { Grobnerhof - Santa } \\
\text { Maddalena Sudtirol DOC } \\
2008\end{array}$ & Italy & $\begin{array}{l}\text { Vinpur } \\
\text { Blancoll }\end{array}$ & $\begin{array}{l}1 \\
2\end{array}$ & $\underset{\mathrm{g} / \mathrm{hL}}{\mathrm{YES}} 15$ & 13.31 & 13.45 & 2.4 & 0.99430 & 3.46 & 28.4 & 27.0 & 4.7 & 0.43 & 2.93 & 1847 & 368 & $\mathrm{Neg}$ & Neg \\
\hline
\end{tabular}




\begin{tabular}{|c|c|c|c|c|c|c|c|c|c|c|c|c|c|c|c|c|c|c|c|}
\hline 46 & $\begin{array}{l}\text { Leuchtenburg Sudtirol - } \\
\text { Kalterersee Lago di Caldaro } \\
\text { DOC } 2009\end{array}$ & Italy & $\begin{array}{c}\text { Vinpur } \\
\text { Biancoll }\end{array}$ & $\begin{array}{l}1 \\
3\end{array}$ & $\begin{array}{l}\text { YES } 15 \\
\mathrm{~g} / \mathrm{hL}\end{array}$ & 13.12 & 13.26 & 2.4 & 0.99328 & 3.44 & 26.0 & 24.6 & 4.5 & 0.43 & 2.60 & 1911 & 293 & $\mathrm{Neg}$ & $\mathrm{Neg}$ \\
\hline 47 & $\begin{array}{l}\text { Primitivo di Manduria DOC } \\
2008\end{array}$ & Italy & $\begin{array}{l}\text { Albovo } \\
\text { Oliver Ogar }\end{array}$ & 6 & NO & 14.41 & 14.5 & 1.5 & 0.99450 & 3.29 & 32.9 & 32.4 & 5.9 & 0.43 & 2.72 & 1864 & 234 & Neg & Neg \\
\hline 49 & Greco di Tufo DOCG 2009 & Italy & $\begin{array}{l}1 \% \text { Egg white } \\
\text { Oliver Star } \\
\text { (caseinate) }\end{array}$ & 1 & YES & 13.23 & 13.39 & 2.7 & 0.99102 & 3.20 & 21.4 & 19.7 & 6.1 & 0.27 & 1.44 & 259 & - & Neg & Neg \\
\hline 50 & Cuxac IGP 2009 & France & Ovoclaryl & 8 & NO & 14.03 & 14.09 & 1.0 & 0.99342 & 3.63 & 28.9 & 28.9 & 4.9 & 0.51 & 2.90 & 2125 & 564 & Neg & $\mathrm{Neg}$ \\
\hline 51 & $\begin{array}{l}\text { Cabernet Franc/Mourvedre } \\
\text { IGP } 2009\end{array}$ & France & Oviclair & 10 & NO & 14.46 & 14.56 & 1.7 & 0.99382 & 3.58 & 31.3 & 30.6 & 5.1 & 0.53 & 2.76 & 2197 & 435 & Neg & Neg \\
\hline 52 & Petit Verdot IGP 2007 & France & Oviclair & 12 & NO & 13.88 & 14.02 & 2.4 & 0.99398 & 3.48 & 30.4 & 29.0 & 5.3 & 0.51 & 2.58 & 1928 & 269 & $\mathrm{Neg}$ & $\mathrm{Neg}$ \\
\hline 53 & Cabezac AOP 2007 & France & $\begin{array}{l}\text { Albumin } \\
\text { poudre } \\
\text { (Laffort) }\end{array}$ & 6 & NO & 13.93 & 14.04 & 1.8 & 0.99343 & 3.52 & 28.7 & 27.9 & 5.2 & 0.43 & 2.34 & 2149 & 285 & $\mathrm{Neg}$ & Neg \\
\hline 54 & $\begin{array}{l}\text { Carignan - Sicard Ignan } \\
\text { AOP } 2009\end{array}$ & France & $\begin{array}{l}\text { Albumin } \\
\text { poudre } \\
\text { (Laffort) }\end{array}$ & 10 & NO & 14.16 & 14.37 & 3.5 & 0.99591 & 3.55 & 35.1 & 32.6 & 5.5 & 0.45 & 3.01 & 2358 & 593 & $\mathrm{Neg}$ & Neg \\
\hline 56 & Caraguilhes AOP 2009 & France & $\begin{array}{l}\text { Albumin } \\
\text { poudre } \\
\text { (Laffort) }\end{array}$ & 10 & NO & 13.75 & 13.87 & 2.0 & 0.99379 & 3.39 & 29.9 & 28.9 & 6.0 & 0.44 & 3.03 & 2999 & 221 & $\mathrm{Neg}$ & Neg \\
\hline 57 & Caraguilhes AOP 2007 & France & $\begin{array}{l}\text { Albumin } \\
\text { poudre } \\
\text { (Laffort) }\end{array}$ & 10 & NO & 13.12 & 13.20 & 1.3 & 0.99444 & 3.55 & 28.8 & 28.5 & 5.1 & 0.46 & 2.55 & 1714 & 277 & $\mathrm{Neg}$ & Neg \\
\hline 58 & $\begin{array}{l}\text { Merlot - Cabernet - Domaine } \\
\text { du Vieux Parc IGP } 2008\end{array}$ & France & Oviclair & 10 & NO & 13.91 & 13.97 & 1.0 & 0.99360 & 3.57 & 29.1 & 29.1 & 5.5 & 0.53 & 2.83 & 2179 & 386 & $\mathrm{Neg}$ & Neg \\
\hline 59 & Corbiéres AOP 2008 & France & Oviclair & 10 & NO & 13.67 & 13.81 & 2.4 & 0.99300 & 3.47 & 27.2 & 25.8 & 4.7 & 0.48 & 2.49 & 2415 & 498 & $\mathrm{Neg}$ & Neg \\
\hline
\end{tabular}




\begin{tabular}{|c|c|c|c|c|c|c|c|c|c|c|c|c|c|c|c|c|c|c|c|}
\hline 60 & $\begin{array}{l}\text { Chateau du Grand Caumont } \\
\text { AOP } 2008\end{array}$ & France & Oviclair & 10 & NO & 12.61 & 12.73 & 2.0 & 0.99334 & 3.43 & 25.5 & 24.5 & 4.9 & 0.44 & 2.29 & 1783 & 354 & $\mathrm{Neg}$ & $\mathrm{Neg}$ \\
\hline 61 & $\begin{array}{l}\text { Château du Grand Caumont } \\
\text { AOP } 2009\end{array}$ & France & Oviclair & 10 & NO & 12.76 & 12.86 & 1.6 & 0.99282 & 3.32 & 24.2 & 23.6 & 5.3 & 0.39 & 2.04 & 1491 & 222 & $\mathrm{Neg}$ & Neg \\
\hline 62 & Listrac - Cuvé 98 AOC 2008 & France & $\begin{array}{l}\text { Egg white } \\
\text { (40 days) }\end{array}$ & 66 & NO & 13.17 & 13.24 & 1.2 & 0.99326 & 3.42 & 26.7 & 26.5 & 5.3 & 0.45 & 2.51 & 2460 & 278 & $\mathrm{Neg}$ & Neg \\
\hline 63 & $\begin{array}{l}\text { Moulis - Cuvé } 56 \text { cru } \\
\text { bourgeois AOC } 2008\end{array}$ & France & $\begin{array}{l}\text { Egg white } \\
\text { (40 days) }\end{array}$ & 66 & NO & 12.95 & 13.01 & 1.0 & 0.99334 & 3.42 & 26.0 & 26.0 & 5.2 & 0.42 & 2.36 & 2283 & 263 & $\mathrm{Neg}$ & $\mathrm{Neg}$ \\
\hline 64 & $\begin{array}{l}\text { Malleret- Cru Bourgeois } \\
\text { AOC } 2009\end{array}$ & France & $\begin{array}{l}\text { Egg white } \\
\text { (3 months) }\end{array}$ & 40 & NO & 12.73 & 12.84 & 1.9 & 0.99496 & 3.58 & 29.7 & 28.8 & 5.0 & 0.51 & 3.18 & 2384 & 289 & $\mathrm{Neg}$ & $\mathrm{Neg}$ \\
\hline 65 & $\begin{array}{l}\text { Corbière Cru Signé AOC } \\
2009\end{array}$ & France & Egg white & US & NO & 13.73 & 13.82 & 1.5 & 0.99354 & 3.45 & 28.7 & 28.2 & 5.1 & 0.39 & 2.44 & 1868 & 421 & $\mathrm{Neg}$ & $\mathrm{Neg}$ \\
\hline 66 & Bois du roi AOC 2007 & France & Egg white & US & NO & 14.61 & 14.74 & 2.2 & 0.99330 & 3.72 & 30.9 & 29.7 & 5.4 & 0.94 & 2.58 & 1604 & 135 & $\mathrm{Neg}$ & $\mathrm{Neg}$ \\
\hline 67 & Montplaisir AOC 2007 & France & Egg white & US & NO & 14.2 & 14.39 & 3.1 & 0.99300 & 3.65 & 28.5 & 26.4 & 4.8 & 0.60 & 2.49 & 1290 & 99 & $\mathrm{Neg}$ & Neg \\
\hline 68 & Echantillon 9B & France & Egg white & $\begin{array}{l}\text { Maximum } \\
\text { dose }\end{array}$ & NO & 10.84 & 12.39 & 25.9 & 1.00504 & 3.42 & 49.5 & 24.6 & 5.4 & 0.76 & 2.72 & 1580 & 167 & $\mathrm{Neg}$ & $\mathrm{Neg}$ \\
\hline 69 & Echantillon 8 & France & Egg white & $\begin{array}{l}\text { Maximum } \\
\text { dose }\end{array}$ & NO & 11.25 & 11.41 & 2.6 & 0.99507 & 3.44 & 25.8 & 24.2 & 5.0 & 0.45 & 2.74 & 1476 & 194 & $\mathrm{Neg}$ & $\mathrm{Neg}$ \\
\hline 71 & Cabernet-Sauvignon 2009 & Australia & Egg White & 4 & $\begin{array}{c}\text { Yes } \\
(1.20)\end{array}$ & 13.29 & 13.37 & 1.4 & 0.99525 & 3,05 & 31.2 & 30.8 & 6,4 & 0,38 & 1.91 & 2171 & 351 & Neg & Neg \\
\hline 72 & Merlot 2009 & Australia & Egg White & 5.9 & $\begin{array}{l}\text { Yes } \\
(0.90)\end{array}$ & 13.31 & 13.37 & 1.0 & 0.99454 & 3.08 & 28.9 & 28.9 & 6,2 & 0,34 & 1.53 & 1967 & 89 & $\mathrm{Neg}$ & $\mathrm{Neg}$ \\
\hline 73 & $\begin{array}{l}\text { Shiraz 55,87\%; Cabernet } \\
\text { Sauvignon } 29,90 \% 2008\end{array}$ & Australia & Egg White & 4 & $\begin{array}{c}\text { Yes } \\
(1.30)\end{array}$ & 13.39 & 13.52 & 2.1 & 0.99527 & 3,03 & 31.5 & 30.4 & 6,3 & 0,41 & 1.95 & 1730 & 264 & Neg & Neg \\
\hline 74 & Shiraz 2008 & Australia & Egg White & 4 & $\begin{array}{c}\text { Yes } \\
(0.18)\end{array}$ & 13.84 & 13.97 & 2.2 & 0.99493 & 3.26 & 32.3 & 31.1 & 6.0 & 0.49 & 2.65 & 1589 & 257 & $\mathrm{Neg}$ & $\mathrm{Neg}$ \\
\hline
\end{tabular}




\begin{tabular}{|c|c|c|c|c|c|c|c|c|c|c|c|c|c|c|c|c|c|c|c|}
\hline 75 & Pinot Noir 2010 & Australia & Egg White & 3.2 & $\begin{array}{l}\text { Yes } \\
(0.01)\end{array}$ & 12.95 & 13.03 & 1.4 & 0.99351 & 3.38 & 26.1 & 25.7 & 5.5 & 0.63 & 2.00 & 1605 & 181 & Neg & $\mathrm{Neg}$ \\
\hline 76 & Cabernet Sauvignon 2008 & Australia & Egg White & 5.3 & $\begin{array}{l}\text { Yes } \\
(4.50)\end{array}$ & 14.23 & 14.30 & 1.1 & 0.99363 & 3.23 & 30.5 & 30.4 & 6.2 & 0.44 & 2.16 & 2365 & 351 & Neg & $\mathrm{Neg}$ \\
\hline 77 & $\begin{array}{l}\text { Cabernet Sauvignon 49,14\%; } \\
\text { Merlot 47,78\% } 2008\end{array}$ & Australia & Egg White & 4.1 & $\begin{array}{l}\text { Yes } \\
(0.72)\end{array}$ & 14.41 & 14.47 & 1.0 & 0.99396 & 3.21 & 31.4 & 31.4 & 6.5 & 0.43 & 2.25 & 2191 & 312 & Neg & $\mathrm{Neg}$ \\
\hline 78 & Shiraz 2008 & Australia & Egg White & 1,7 & $\begin{array}{l}\text { Yes } \\
(8.50)\end{array}$ & 13.66 & 14.00 & 5.7 & 0.99677 & 3.03 & 36.7 & 32.0 & 6.4 & 0.41 & 2.05 & 1876 & 364 & $\mathrm{Neg}$ & $\mathrm{Neg}$ \\
\hline 79 & Shiraz 2007 & Australia & Egg White & 3 & $\begin{array}{l}\text { Yes } \\
(2.20)\end{array}$ & 14.58 & 14.65 & 1.1 & 0.99440 & 3.23 & 33.6 & 33.5 & 6.4 & 0.51 & 3.00 & 1835 & 235 & Neg & $\mathrm{Neg}$ \\
\hline 81 & Cabernet Sauvignon 2008 & Australia & Egg White & 1 & $\begin{array}{c}\text { Yes } \\
(0.51)\end{array}$ & 14.15 & 14.21 & 1.0 & 0.99406 & 3.06 & 31.2 & 31.2 & 6.6 & 0.42 & 1.97 & 2408 & 360 & Neg & $\mathrm{Neg}$ \\
\hline 82 & Pinot Noir 2009 & New Zealand & $\begin{array}{c}\mathrm{CuSO} 4.5 \mathrm{H}_{2} \mathrm{O} \\
1.12 \mathrm{mg} / \mathrm{L}, \\
\mathrm{Egg} \text { white } 2.5 \\
\mathrm{mg} / \mathrm{L}, \mathrm{Laflort} \\
\mathrm{Gecoll} 2.42 \\
\mathrm{mg} / \mathrm{L}\end{array}$ & 0.60 & NO & 14.85 & 14.98 & 2.1 & 0.99212 & 3.47 & 28.4 & 27.3 & 5.4 & 0.64 & 2.14 & 1402 & 152 & Neg & $\mathrm{Neg}$ \\
\hline 83 & Pinot Noir 2009 & New Zealand & $\begin{array}{c}\mathrm{CuSO} 4.5 \mathrm{H}_{2} \mathrm{O} \\
0.59 \mathrm{mg} / \mathrm{L} \\
\text { Laffort Gecoll } \\
0.2 \mathrm{mg} / \mathrm{L}\end{array}$ & 0.075 & NO & 14.60 & 14.71 & 1.9 & 0.99340 & 3.62 & 30.7 & 29.8 & 5.4 & 0.67 & 2.52 & 1412 & 152 & Neg & $\mathrm{Neg}$ \\
\hline 84 & Vino Navarra Reserva 2004 & Spain & $\begin{array}{l}\text { Albumin } \\
\text { (Lamothe } \\
\text { Abiet) }\end{array}$ & 5 & NO & 13.64 & 13.73 & 1.5 & 0.99446 & 3.13 & 30.3 & 29.8 & 6.2 & 0.41 & 1.66 & 2296 & 129 & Neg & $\mathrm{Neg}$ \\
\hline 85 & Ysios Reserva 2005 & Spain & $\begin{array}{c}\text { Ovocol L } \\
\text { (Martin } \\
\text { vialatte) }\end{array}$ & 46.6 & NO & 13.66 & 13.80 & 2.4 & 0.99389 & 3.27 & 29.3 & 27.9 & 5.3 & 0.47 & 2.21 & 1962 & 223 & Neg & $\mathrm{Neg}$ \\
\hline
\end{tabular}

BEN: use of bentonite; ASV: Alcoholic Strength by Volume; TAS: Total Alcoholic Strength; RS: Reducing Sugars; TDE, Total Dry Extract; RE, Reduced Extract; TA: Total Acidity; VA: Volatile Acidity; TPC: Total Phenolic Compounds; TAC: Total Anthocyanins; IMM: Immunoblotting; Neg: negative. 
Figure 1 - SDS-PAGE (A) and Immunoblotting (B) of two fining agents containing egg white proteins and purified fractions from hen egg white. The antibody used in immunoblotting was the anti total egg white proteins.

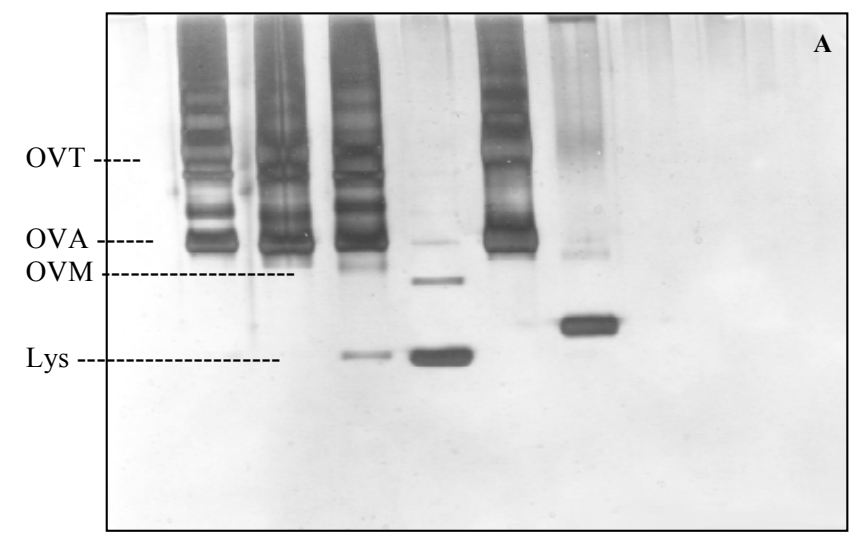

EW1 EW2 WE Lys OVA AV

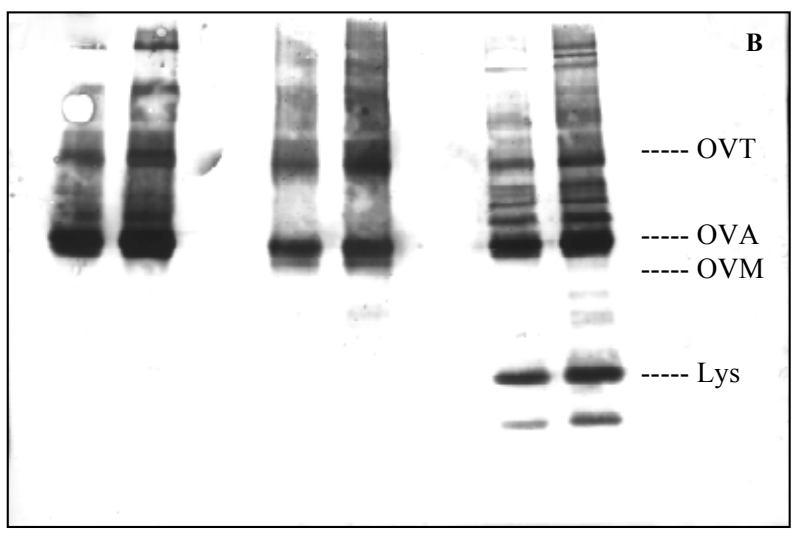

EW1 EW1

EW2 EW2

WE WE

FIGURE 1

\section{Legend}

EW1 $=$ commercial oenologic egg white ${ }^{\circ} 1$

EW2 $=$ commercial oenologic egg white $n^{\circ} 2$

WE = whole egg

Lys $=$ lysozyme

OVA $=$ ovalbumin

$\mathrm{AV}=$ avidin

OVT $=$ ovotransferrin

OVM $=$ ovomucoid 
Figure 2 - Immunoblotting of different commercial red wine samples obtained by incubating the PVDF membrane with the anti-total egg white protein antibody. (A) Italian red wine samples; (B) Australian red wine samples.

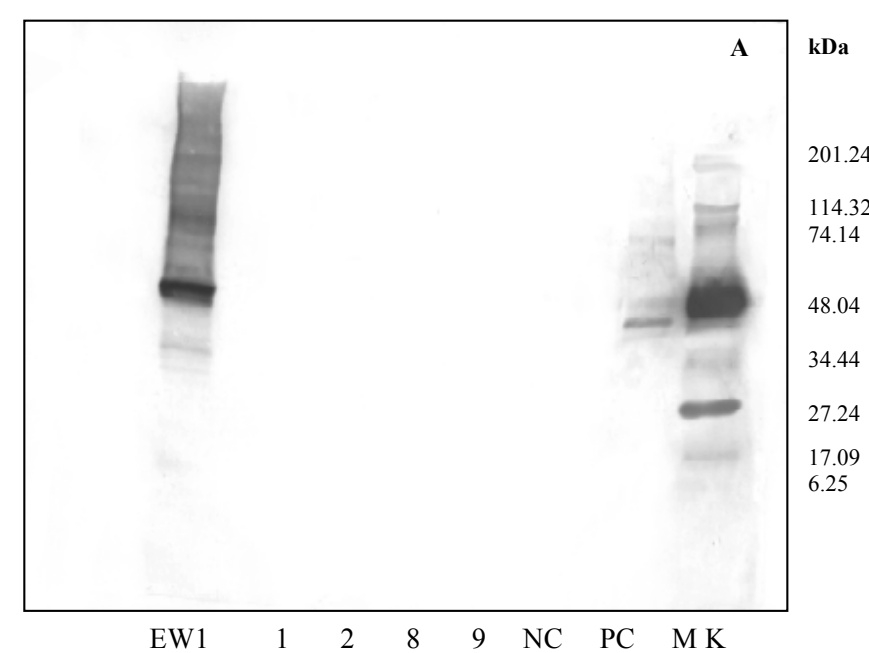

\section{Legend}

EW1 $=$ commercial oenologic egg white ${ }^{\circ} 1$

$1-2=$ commercial Italian red wines fined with egg white proteins $8-9=$ untreated commercial Italian red wines

$70-73=$ commercial Australian red wines fined with egg white proteins

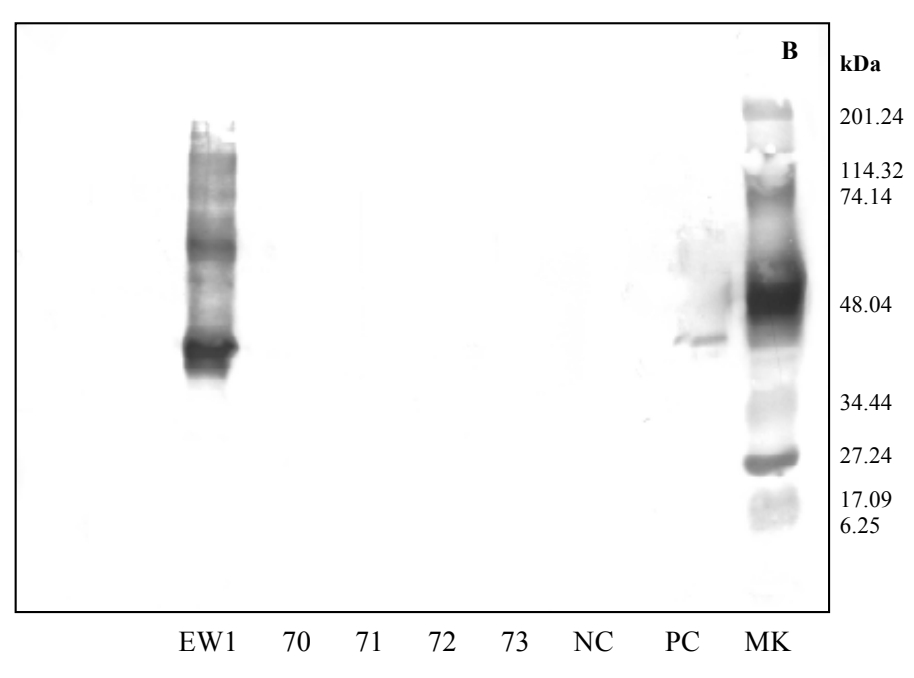

$\mathrm{NC}=$ negative control (unfined red wines)

$\mathrm{PC}=$ positive control (wine $+1 \mathrm{ppm}$ albumen $)$

$\mathrm{MK}=$ prestained SDS-PAGE standards 